birthday. Another objectionable feature is that we are shown Pasteur hurrying from one doctor's house to another on a rainy night to find an accoucheur for his daughter, the wife of one of his former opponents, and after a prolonged and fruitless search at last persuading the president of the Académie de Médecine, his chief antagonist, to carry out the confinement under antiseptic precautions. The doctor's consent, however, was only obtained on the condition that Pasteur signed a document to be published in the medical press that his researches in rabies had been a failure.

THE film, therefore, scarcely deserves the high praise given it by certain writers in the daily Press obviously unfamiliar with the details of Pasteur's life and work. A word of commendation, however, must be given to the producers, Messrs. Warner Brothers Pictures, Ltd., for the excellent background representing a doctor's consulting room in pre-antiseptic times, the rural scenery and Pasteur's laboratory. In a film of this sort, intended for entertainment rather than for instruction, it is possibly pedantic to expect absolute historic accuracy. It must be admitted that an average audience will probably obtain from the film some idea of what a scientific attitude implies. They will certainly realise something of the thrill of successful research, as well as the drudgery and self-sacrifice which it involves. Also, there will be no doubt left in their minds regarding the social implications of the work of the man of science. The film was shown by permission of Gaumont British.

\section{Australian Research Ship}

THE Commonwealth Council for Scientific and Industrial Research is about to build a specially designed Diesel-engined steel vessel for an extensive study of fish life in the ocean waters around Australia. Since the loss of the trawler Endeavour in 1914, with Dannevig on board and, presumably, the greater part of his records also, no systematic investigation of Australian fishing grounds has been carried on. The new vessel cannot be used for trawling, being designed mainly for the catching of surface swimming or pelagic fish by purse seine (and ring) nets ; but it will be able to do a certain amount of work on demersal fish by means of Danish seine nets. The principal fish to which attention will be given at first are pilchards, Australian salmon, garfish, barracouta, members of the mackerel family including tunny, and other edible species. The length of the vessel will be $82 \mathrm{ft}$. and its beam $19 \mathrm{ft}$. Its extreme draught will be $8 \mathrm{ft} .4 \mathrm{in}$., and its displacement $108 \cdot 5$ tons. It will be capable of a speed of nine knots.

\section{Australian Aborigines and Prospectors}

Australian aborigines are said to have attacked and attempted to spear a party of gold prospectors who were searching for Lasseter's Reef, which is supposed to be rich in gold, and has been sought by such expeditions for years. According to reports from Alice Springs, it is stated in a dispatch from the Adelaide correspondent of The Times in the issue of
June 18, aeroplanes from Sydney reached Mount Bowley, a native reserve fifty miles from the West Australian border, on June 14, and the attack took place while the occupants were awaiting the arrival of the ground party with trucks. The blacks began by firing the porcupine grass, and after one of them had tried unsuccessfully to barter geological specimens, a group in war paint appeared and hurled spears. One prospector narrowly escaped being hit. The white party, which was armed with rifles and revolvers, then attacked and charged several times through the scrub, while further spears were thrown at them. No member of the party was injured. An investigation no doubt will be held. It will be important to know whether the attack was entirely unprovoked, or whether the party had unwittingly infringed what the tribesmen regard as their rights. The name of the tribe responsible is not mentioned, even if known; but neither the Arunta nor their neighbours, the Loritja, to whom the aggressors more probably belonged, according to recent accounts of them, are fiercely aggressive and liable to attack without reason, as are the northern saltwater blackfellows of Arnhem Land, who were responsible for the murder of Trooper McColl two years ago. Fear for their water supply is a frequent cause of trouble, and if prospectors for minerals are to be allowed to enter the reserves--generally it has been understood that this was forbidden-the risks of interference with tribal water-holes should be understood.

\section{Transport Conditions in New York}

AFTER studying transport conditions in America, Mr. J. P. Thomas, the manager of the London Transport Board railways, on his return to London gave an interview which is reported in The Times of June 19. He pointed out that New York would probably adopt a unified system of transport similar to that in use in London. He mentioned that the rush-hour problem in New York is as perplexing as in London, and intensive services have to be pressed into operation for very short periods at certain times of the day. In New York, certain business hours have been voluntarily altered by large offices and works so as to mitigate largely these rushes, with satisfactory results. If London firms would co-operate by altering the times of arrival and leaving of their staffs by 20 or 30 minutes, equally satisfactory results could be obtained, especially in the centre of the city. Mr. Thomas comments on the severely utilitarian appearance of New York's stations and on the difficulty of finding them, but he praises the efficiency of the underground staffs. $\mathrm{He}$ was impressed by the fact that the acceleration and retardation of trains in New York is much higher than in London, and yet they run equally smoothly. On some of the trains in New York, the acceleration is at the rate of three miles an hour a second and the retardation at the rate of four miles an hour a second. These rates are at least twice the rates at present adopted in London. Experiments have been carried out for some time in London on the 'Metrodyne' train. The experience gained in New York confirms the usefulness of this type of train, and the desirability of higher speeds. 